\title{
La Historia del Arte ilustrada de Manuel Jaén
}

\author{
Rosario Camacho Martínez \\ Universidad de Málaga
}

El hombre de todas las épocas se ha interesado por el arte. Si la regla no conoce excepciones, justo es agregar que ninguna época ha sentido por la imagen una pasión comparable a la nuestra. René Huyghe

\section{Presentación}

Cuando, hace unos meses, mi buen amigo Manolo Jaén se presentó en mi Facultad con unos gruesos volúmenes que me pidió que examinara, no podía ni imaginar que me iban a proporcionar tan grata y didáctica lectura.

Su padre, don Manuel Jaén, también arquitecto y magnífico dibujante, había dedicado muchas horas de su vida a escribir e ilustrar una Historia del Arte Universal , nunca publicada y tampoco terminada, pues en tan ardua tarea consumió sus últimos años, con un extraordinario sentido didáctico que, presentada en viñetas y descriptivos textos, indudablemente tenía que llegar a un público muy amplio, empezando por aquellos que no conocían la historia del arte. Ya en la introducción el autor presentaba la metodología y exponía las intenciones que le llevaron a realizar esta "historia pensada, escrita y dibujada para chicos y grandes».

En esta obra, en la cual está presente el recuerdo de las antiguas enciclopedias escolares, no solo destaca su interés por la arquitectura, sino también su afán por el conocimiento y presentación de las otras artes, manifiestos en los claros esquemas y dibujos que acompañan a las concisas y exactas descripciones, un texto no desprovisto de erudición, porque son muchos los datos aquí acumulados, pero carente de pedantería. Y no se reducía solo al arte occidental, pues aunque no pudo completar su programa, no empezó por lo más conocido sino que el arte del extremo oriente, el de la América precolombina y otros, están presentes en esta obra entrañable.

Con un dibujo vivo y escueto, don Manuel nos daba su versión icónica a través de cuadros o episodios bien conocidos, presentando otras veces imágenes de su propia invención, no tanto apoyadas en otras obras, pero en las que 
destaca siempre su soltura y expresividad, demostrando una vez más la importancia de la imagen. Por otro lado, los textos rezuman claridad, sencillez y sentido del humor, tal vez para tratar de acercarse a sus lectores de una forma más asequible, y siempre en consonancia con las imágenes.

El arte es un conjunto de lenguajes con unas estructuras propias y yo me encontraba con un libro ilustrado donde se había establecido perfectamente la relación entre lo que el lector lee y lo que ve. Pero hay algunas diferencias respecto a uno de los lenguajes de nuestra cultura visual de masas, el "cómic", un medio icónico-verbal en el cual sus dos componentes, el literario y el visual, son inseparables.

Lo que aquí nos encontramos es un doble lenguaje, el verbal y el icónico, como complemento y refuerzo uno de otro. Estas imágenes ilustran relatos. Tanto unas como otros nos ofrecen información. $Y$ con esta se construye la historia. Según Manguel, nuestra existencia transcurre en un despliegue de imágenes captadas por la vista, realzadas o atenuadas con la ayuda de los otros sentidos, con las cuales construimos un lenguaje hecho de imágenes traducidas a palabras y de palabras expresadas en imágenes, a través del cual tratamos de comprender nuestra propia existencia. Formalmente los relatos existen en el tiempo y las imágenes en el espacio. La palabra escrita, el texto, fluye constantemente, no queda limitada por la página, ni siquiera por el capítulo. El relato es lo opuesto al instante, o al menos puede superarlo o anularlo, indica Juan Antonio Ramírez. La imagen fija la idea, es como una instantánea; existe en el espacio que ocupa, independientemente del tiempo que dediquemos a su contemplación.

Y en estas coordenadas se mueve don Manuel Jaén. El texto, en general, es autosuficiente, pero con las imágenes la comprensión se complementa, se duplica.

El libro se dirige a un público que no tiene nociones de la historia del arte, cuyos conocimientos pueden ser muy básicos y no tiene la capacidad de relacionar el arte con la historia, de ahí los explicativos contextos, pero también está dirigida a los que saben, como recuerdo, como un golpe a la memoria. Manuel Jaén utiliza todos los medios que cree necesarios para su fin, que es explicar cómo a lo largo de la historia han ocurrido hechos, circunstancias, opciones, que se han manifestado de una u otra forma, o se han expresado mediante símbolos, o han ejercido una función, hechos u objetos tanto materiales como inmateriales que se han podido concretar en determinados hitos, que vienen a constituir el universo del arte que nos envuelve. 
Cabe comprender la importancia de una obra como esta, que podemos juzgar como una introducción al arte en el sentido de que es una buena visión previa y también porque introduce, penetra en el sentido del arte.

Evidentemente lo que pretendo con estas palabras preliminares es manifestar, comunicar al lector, lo mucho que me ha interesado este trabajo, inmenso, arduo, claro, sugestivo, emocionante y cómo, a través de su lectura, he sentido una gran afinidad con las intenciones del autor. He admirado su vasta cultura, su afán por comunicarla a los demás, su capacidad de síntesis, su claridad en la exposición, su destreza para el dibujo, su ingenio para engendrar imágenes y su capacidad para manipularlas.

Por supuesto que sus intenciones de difusión y divulgación de la historia del arte están cumplidas, pero no dudo de su disfrute al realizar esta obra. Ojalá también, de algún modo, tal vez presentándolo, en su momento, a sus familiares y amigos, se hubiera sentido satisfecho por su capacidad para hacer disfrutar a sus lectores.

(A continuación presentamos algunos fragmentos escogidos de esta historia ilustrada del arte de Manuel Jaén Albaitero, correspondientes a diversos periodos del arte en la India, y entresacados del tomo IV de la obra. Hemos querido mantener aquí la maquetación original, en bruto, de Manuel Jaén). 



\section{Savia}

\section{Fragmentos escogidos de La Historia del Arte ilustrada de Manuel Jaén}

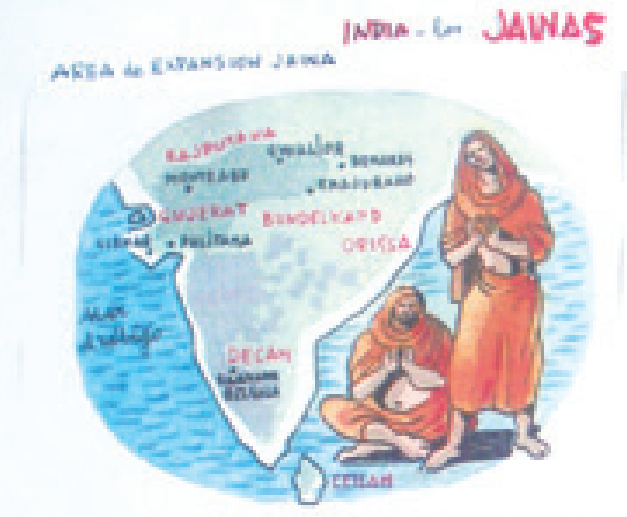

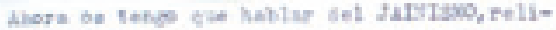

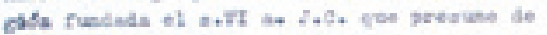

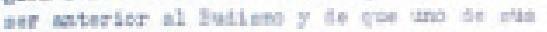
nonjes fut maeatrs de Bakis Mash, thets yque

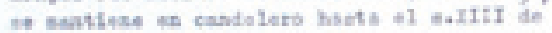
J.C. Jerbs +12a ol surtandente te vesee con

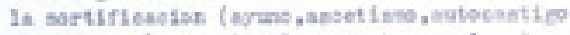

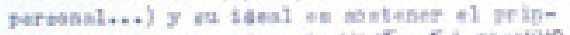
eiple be no rzotcicta, el rejrets a Side see vive TENTLE EN GIRNA \&.

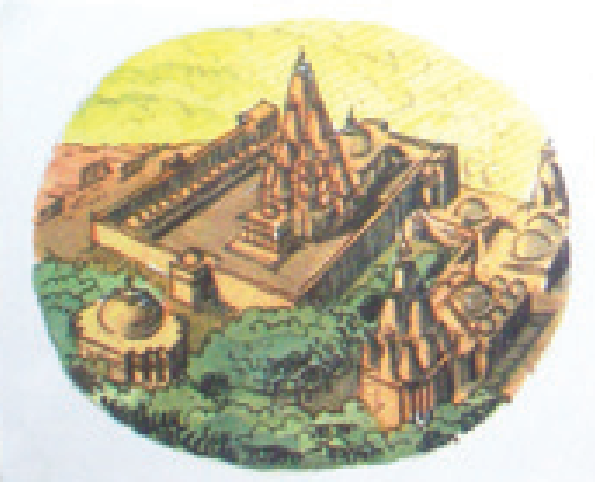

w anelezan botatrigesdo levples to nadera $y$

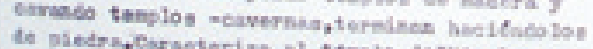

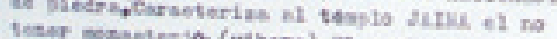

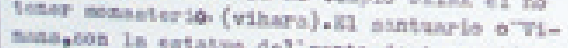

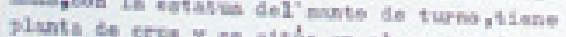
plunth de crua $y$ as asias sh et centro de ap

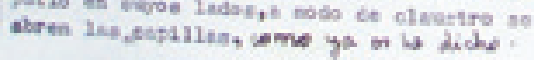

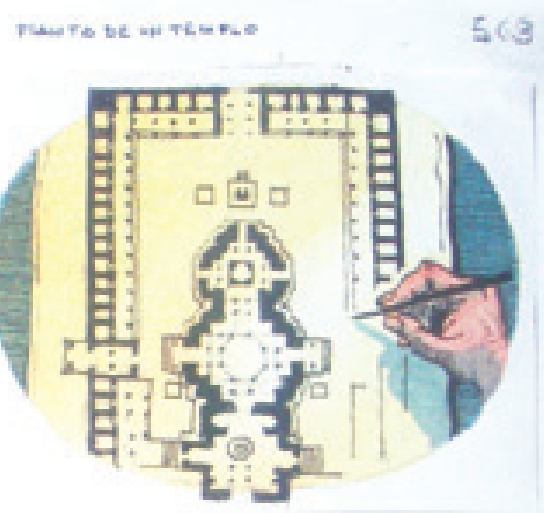

Us nooje Inin proyects un tesplo encerrede vu rebinte por und Eursila,

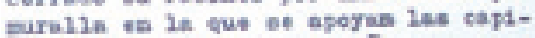
llan gue robeas un patie. En su centro se levants el Oram Sentuar1o, owgt planta veie en el erequis que ví traratade,

$$
\text { LA "SaikaRBa" JUINA }
$$

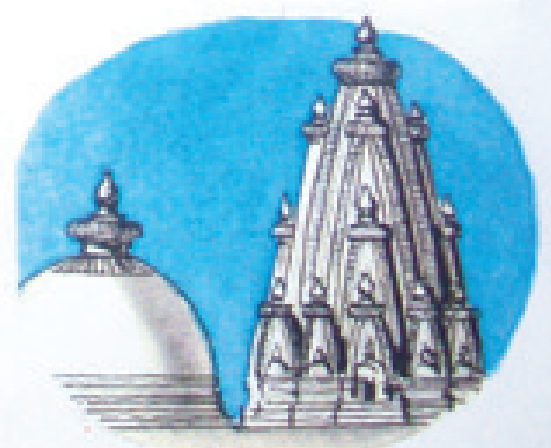

La elfisea "abikara" que et elava ta los templos jaim del Gajerat floate

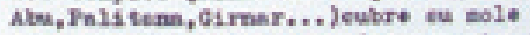
pirasal de caras curvadad, eon otras sediss "shikaras" gue ee aplastan to cllas $y$ cuyo tanafio diseinuge bacie 1a bete, Gobe remate, el fruts sogrede, 1n "annlekn". 


\section{SEvaria}

\section{INDIA Le JAINAS} SISTEM CENSTENLTIVO JAINA

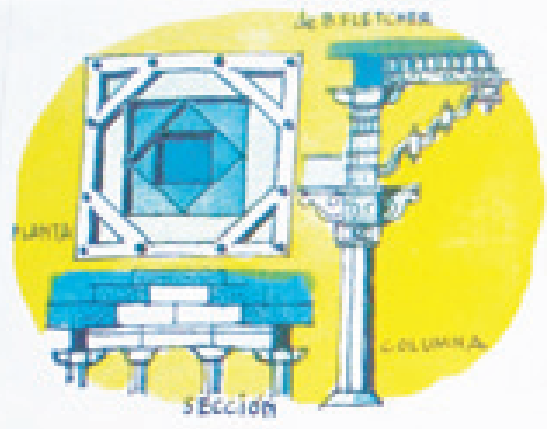

ice of interisr, nonelfilee, is piedra tath ifto bujala Imitudo lan forakn de moderk, oot con-

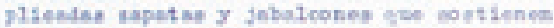
techos formalos $\boldsymbol{\gamma}$. hiksias horisontalee que ne rac eetrabids th oeterab cads ves mas pegueling hastn denapratecer ez 19 alto. Keto semonotrs is exieteocia unterior le tere plos te eatruetura lefises.

TEMPO \& NEMNST in DISWAREA (NWT ABU)

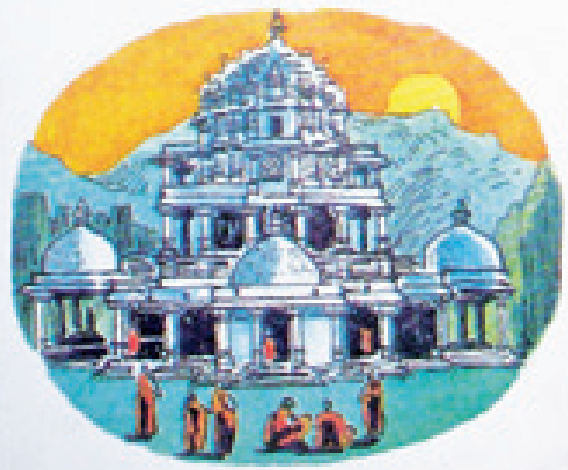

Otre eantre relleioso JADE, ptra verdatera ciulad be teeplon $y$ monatteriog,en Honte ABA Fed wo de lo iraramerablen templos be Dd1 unrraten el gae $1 \mathrm{~s}$ eskelts "vikars" ha sido wae. istulda par una cinulh toe expeers al axte-

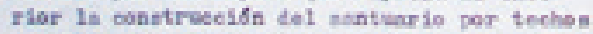

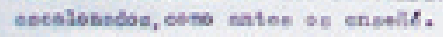

PALITANA

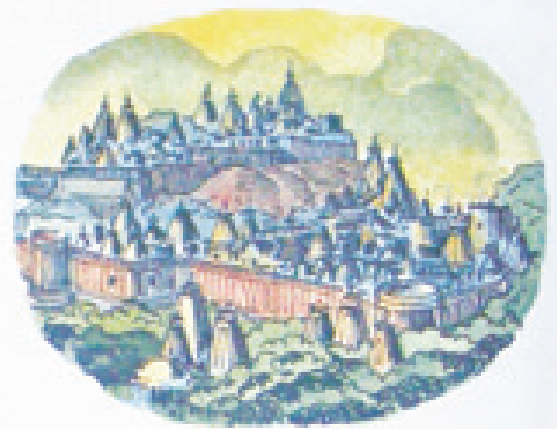

81 eonjuevs do Palitua (ez el Oujarat)forat

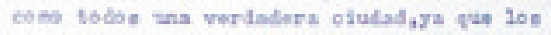
templos sen habludos exeleairaseste por los dipets y los son fes viven fuera del reelsto que esstiene loe teeplos.

Los Jainas eliceh pura ellos afncaleres pafnjes, eono si in naturalens turiese sue res-

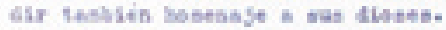

INTE R.IOR

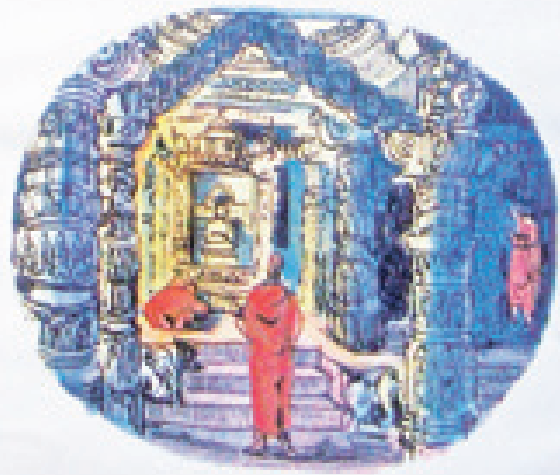

gI interior de los tenslas se decora ean an ornanentueida exputernato gue evire toa wroes, pilaces y techos, masta es lon san enced-

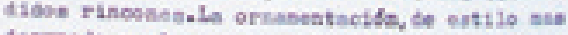
Aeprerado $y$ elecuste que la bditesy obavier to en easeje de nírol blacee tods re ruperrleie. 


\section{e varia}

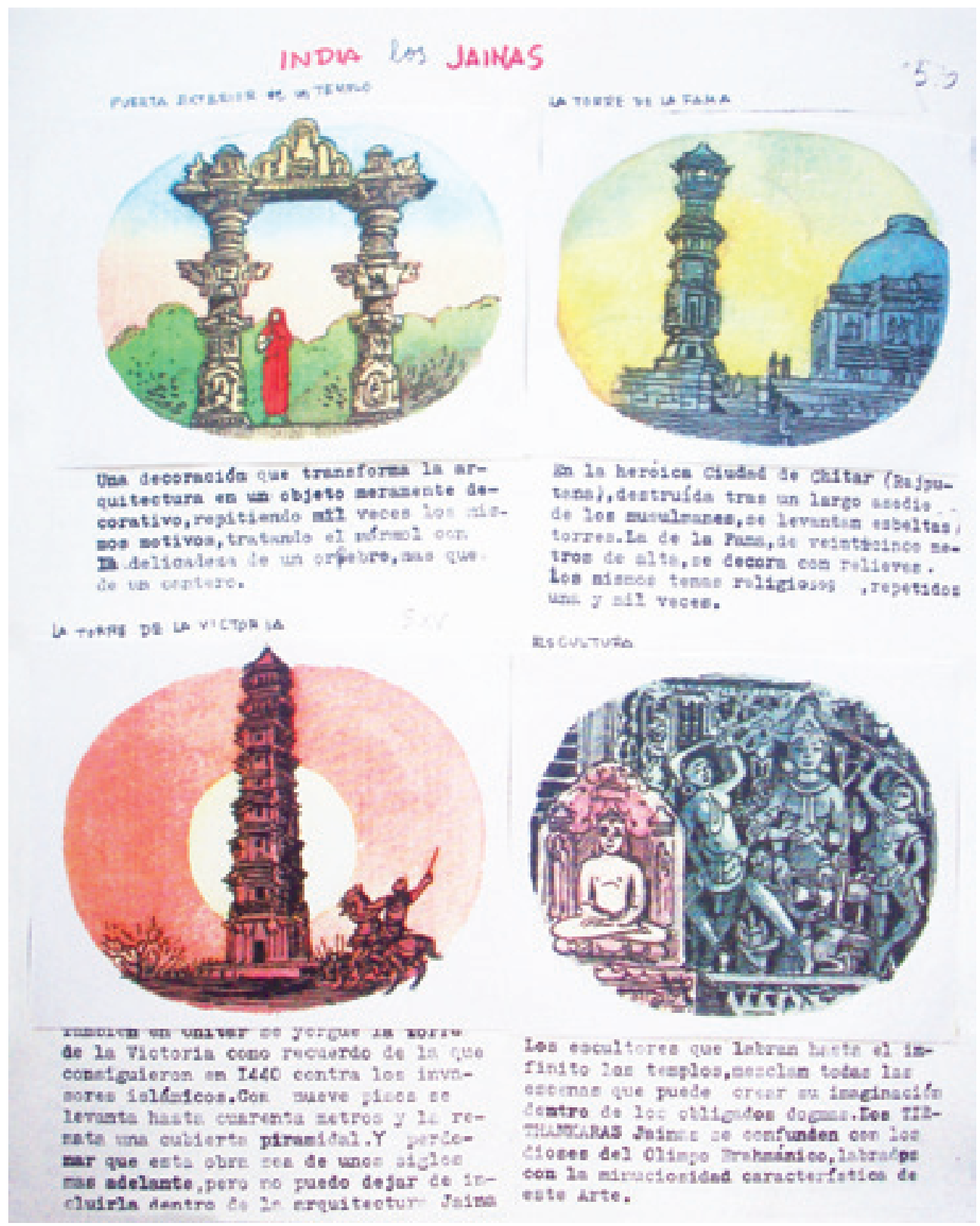




\section{E varia}

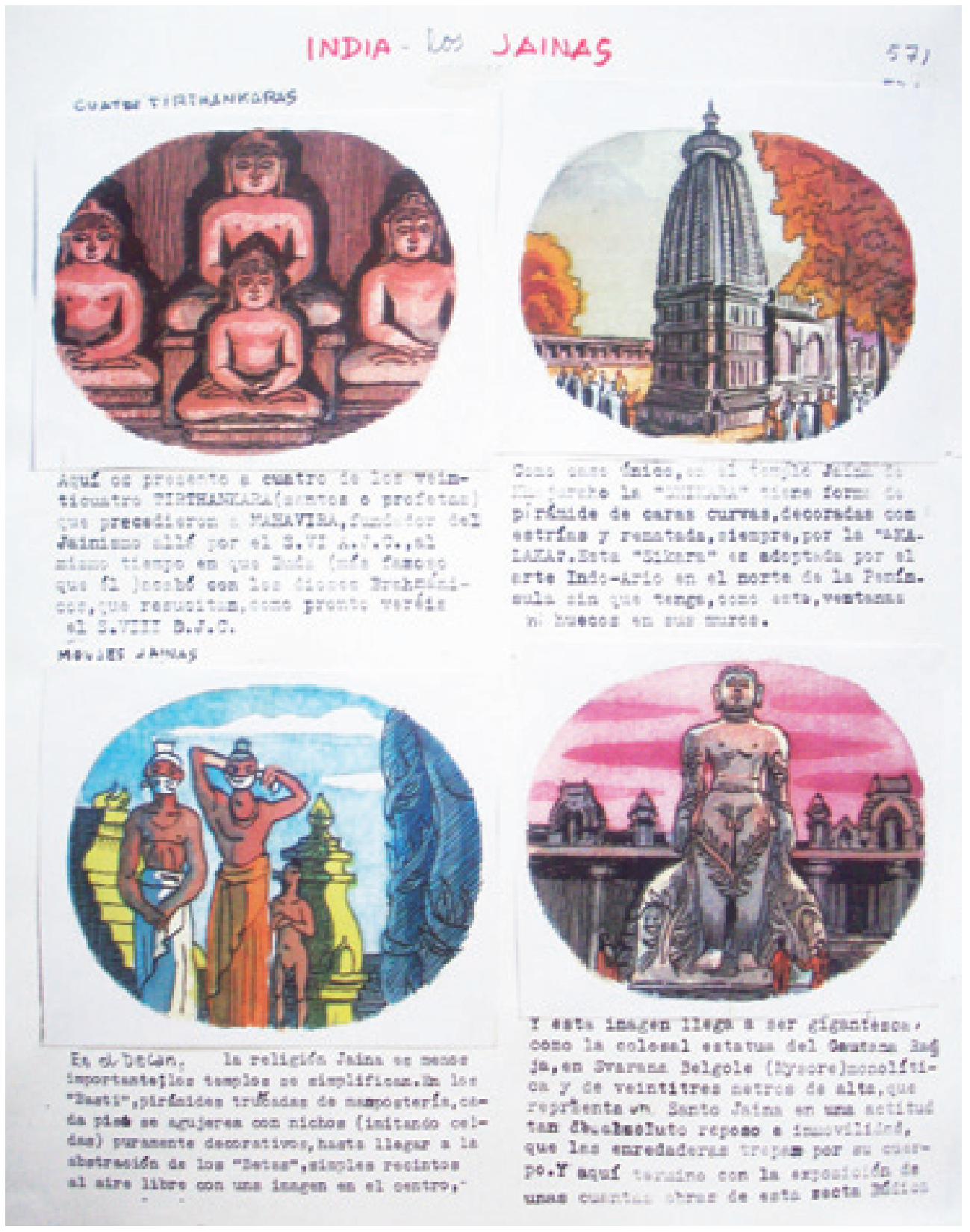




\section{e: varia}

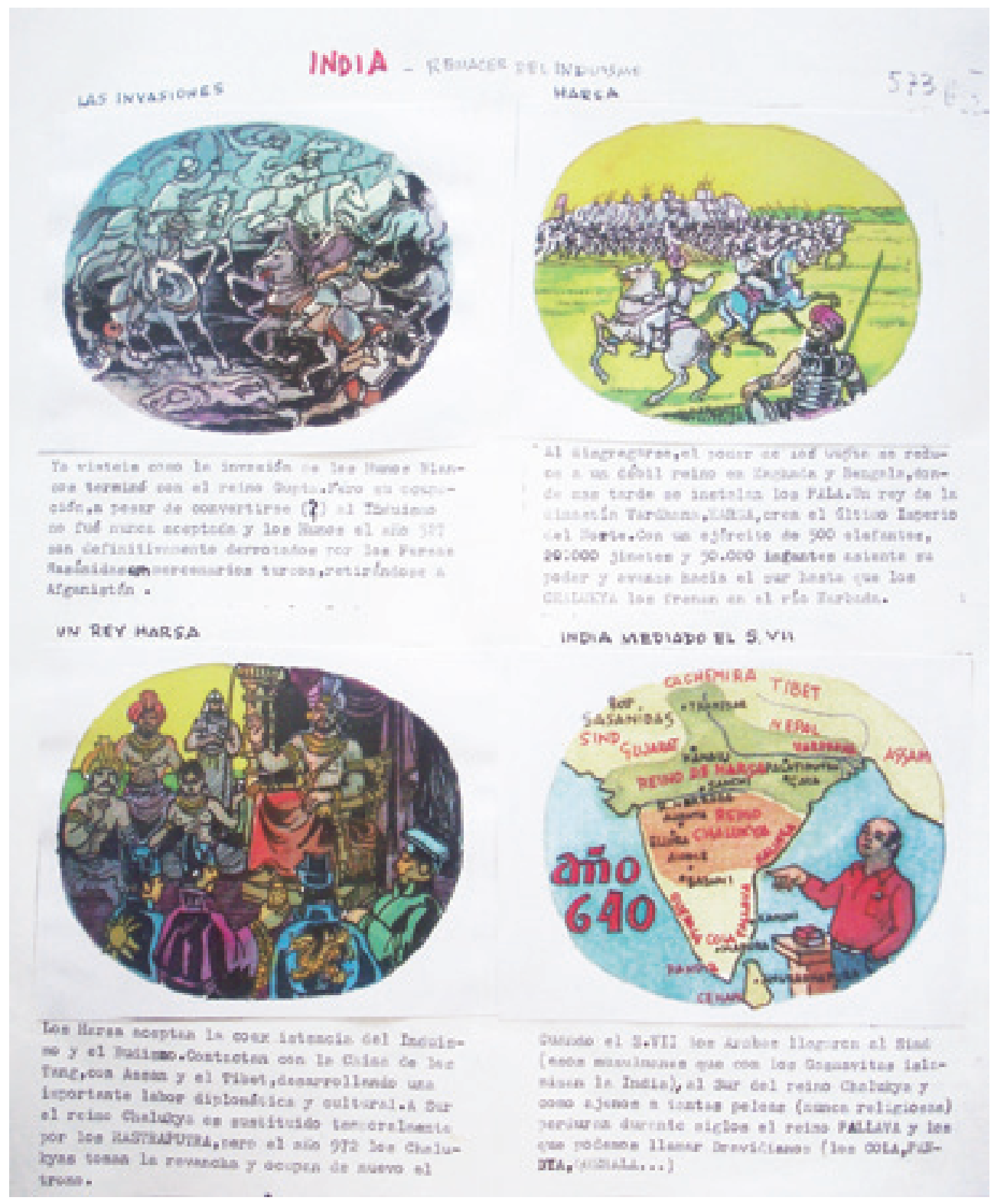




\section{E varia}

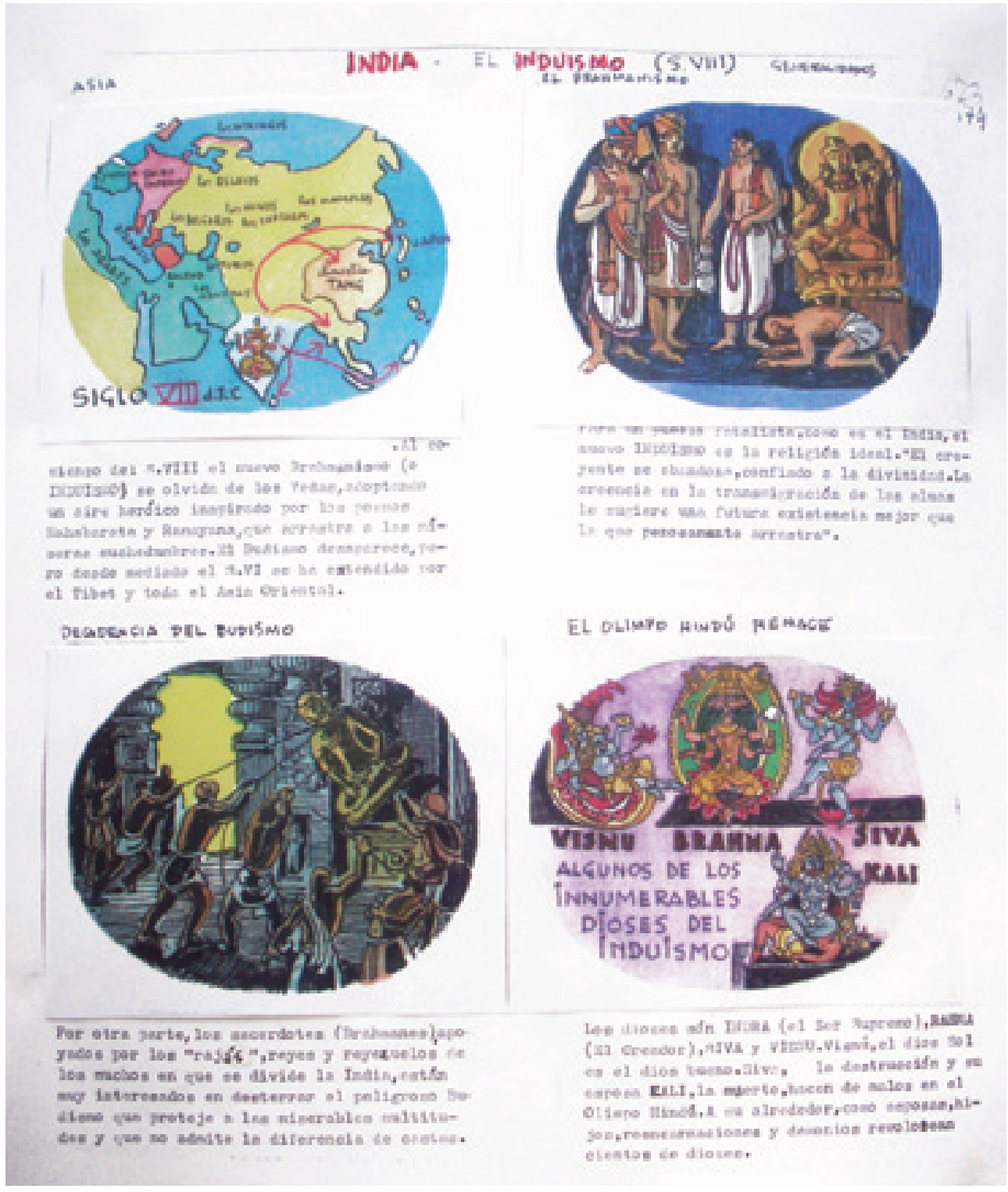




\section{e varia}

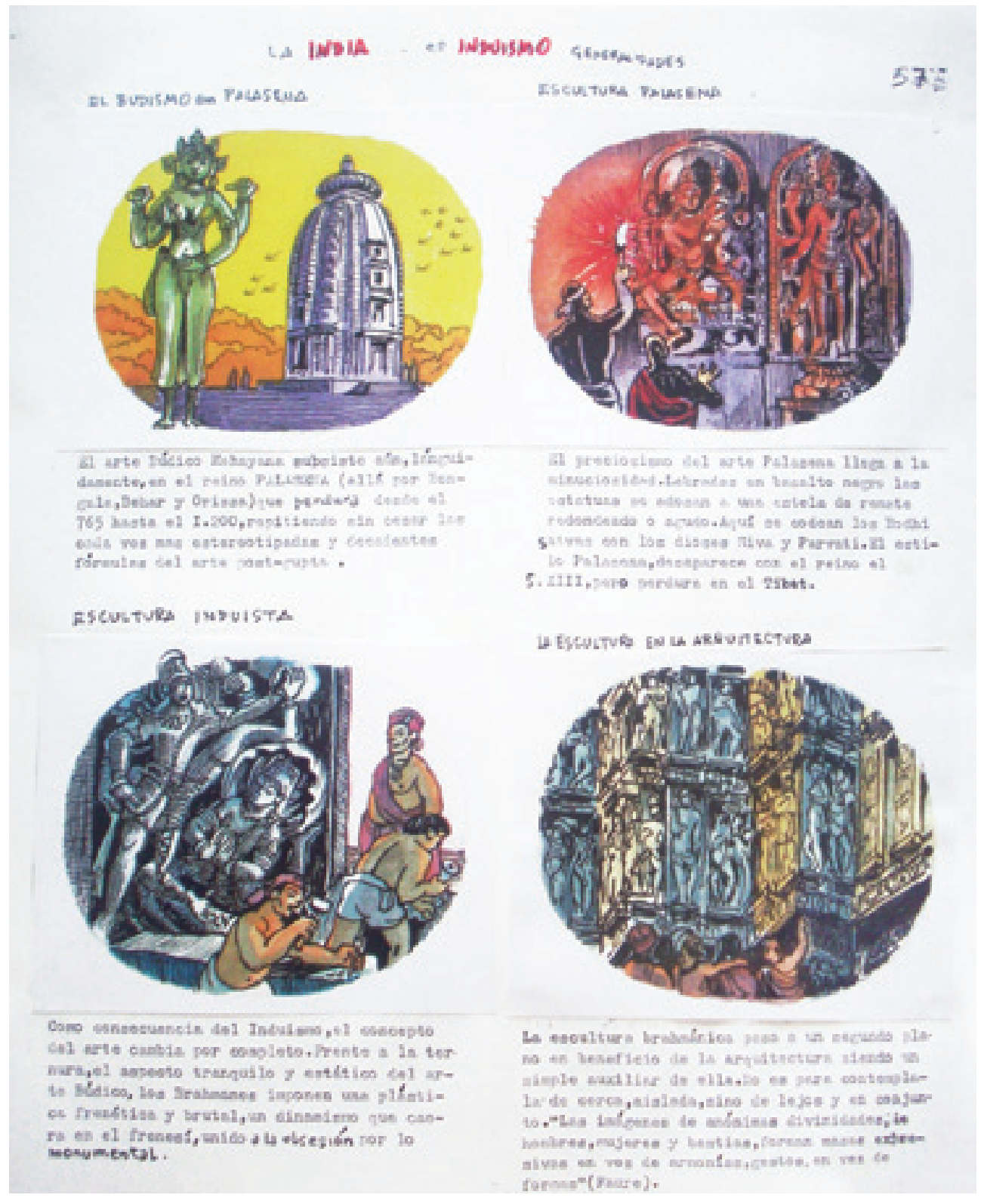




\section{e varia}

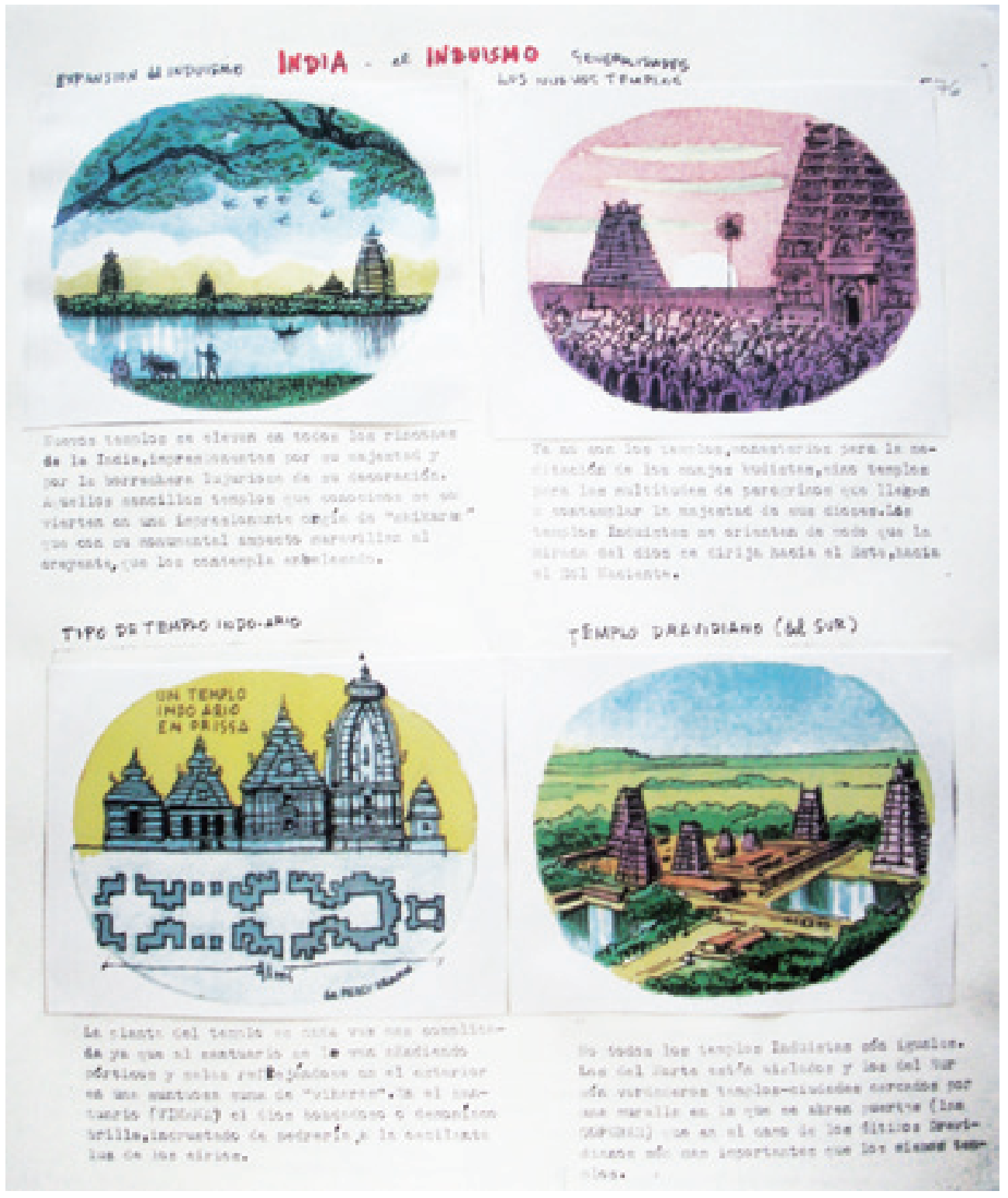




\section{E varia}

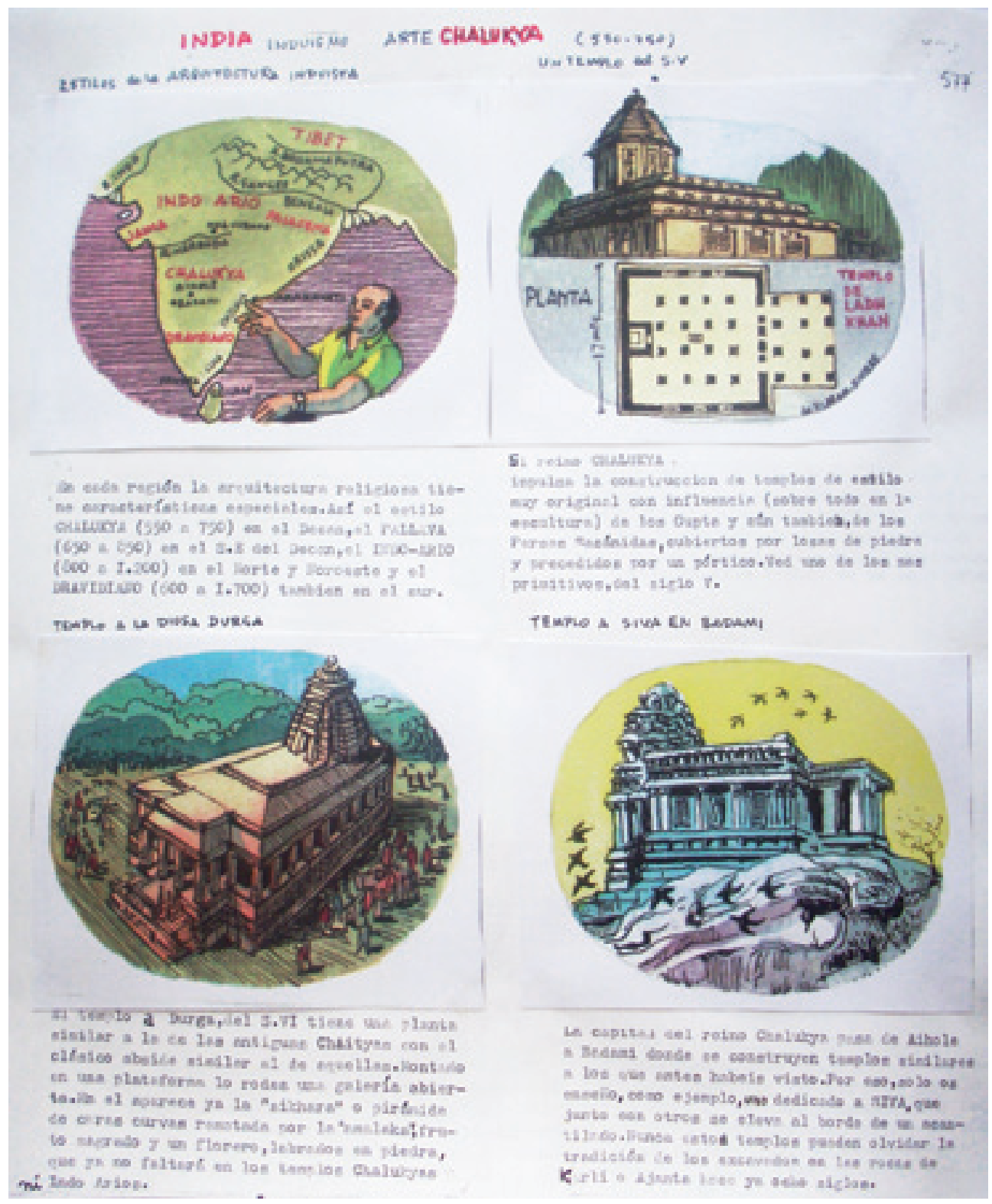




\section{Q}

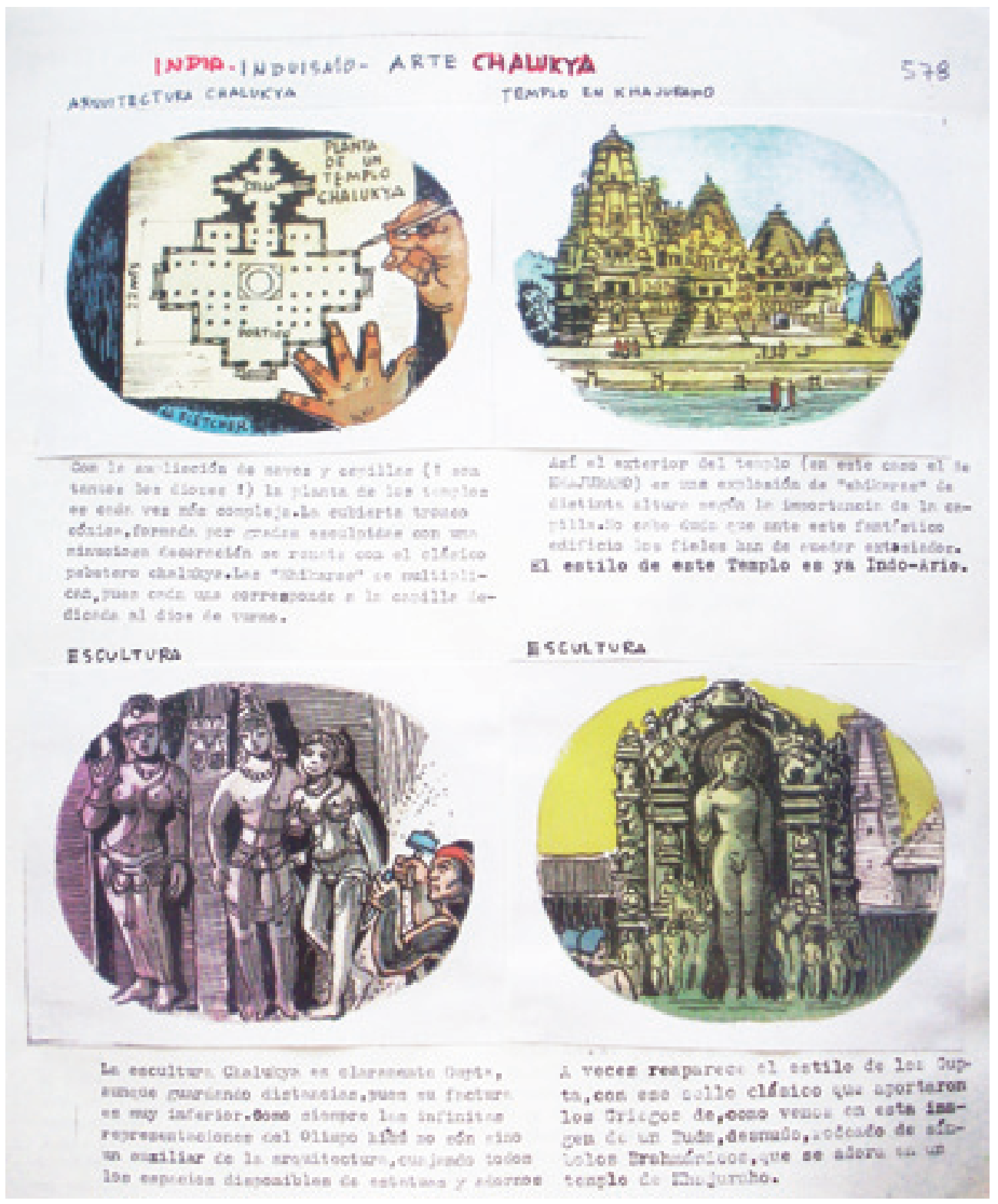




\section{Saria}

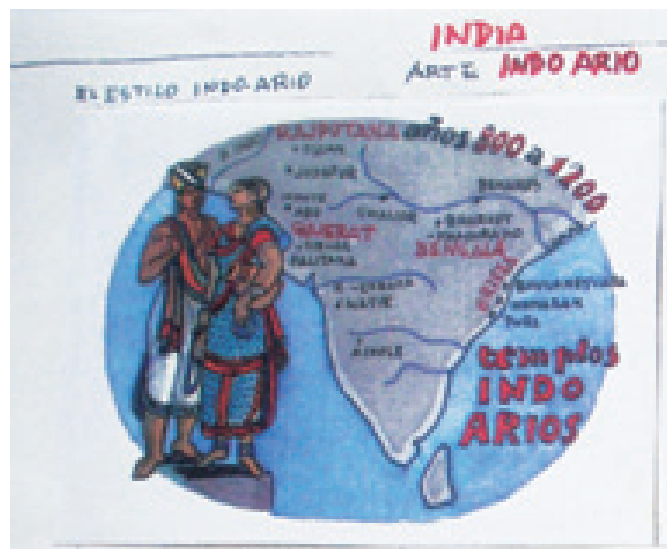

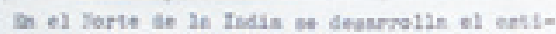

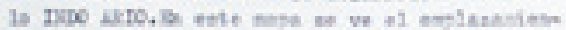

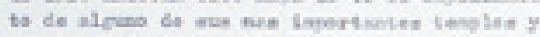

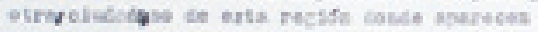

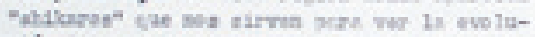

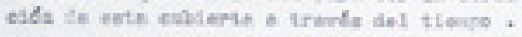

\section{s airians}

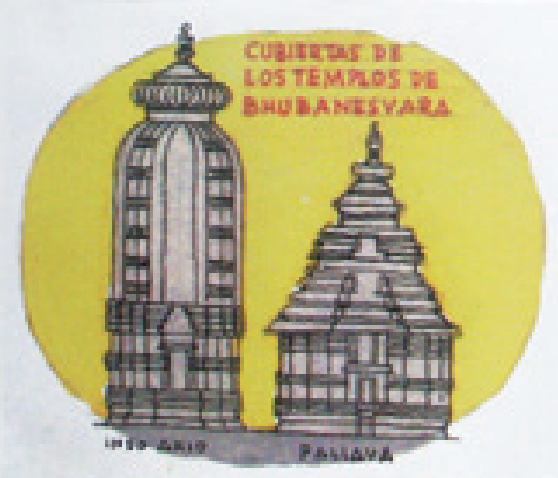

Son cot las sinet te edbiertrs ukidss per lot

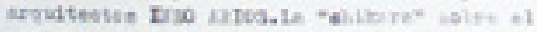

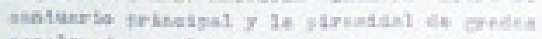

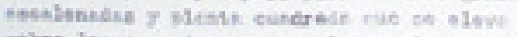

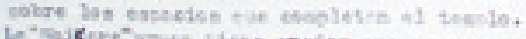

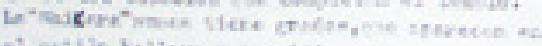

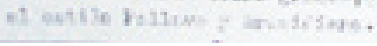

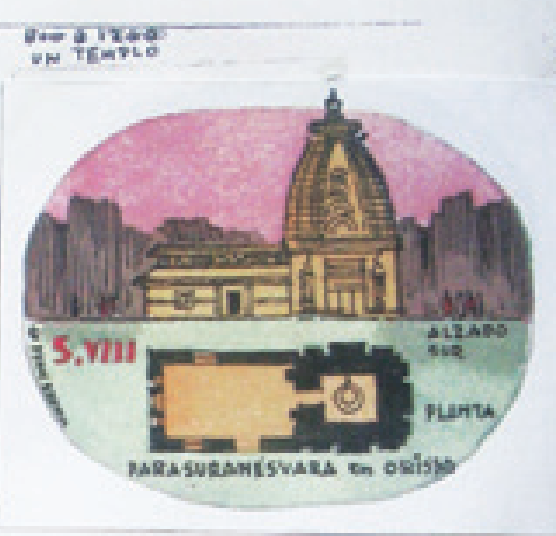

Le pons de Criman at Ilera to templest

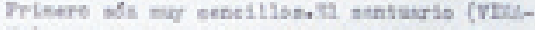

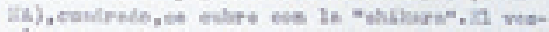

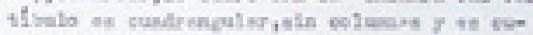

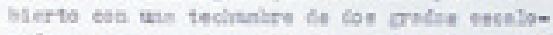
nirdite

\section{EVDLUCIOA DE LA SHIKARA}

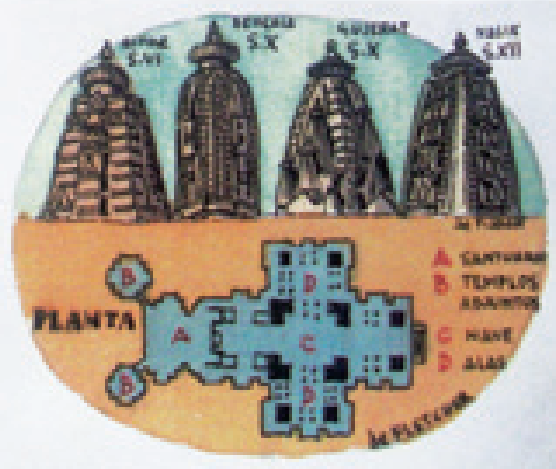

A lo large de los alglog la "Shikara'varfo mas th los detallea sue on ru silusta, La planta de los temploe en oruciforno $y$ aque1.a tiene forms sceapensila esh un reate yedondendo que resata vea thoret "jelaka", Las cornitus te decoran con arees do Merradors sue se sugerpenen on tods su strurs. 


\section{E varia}

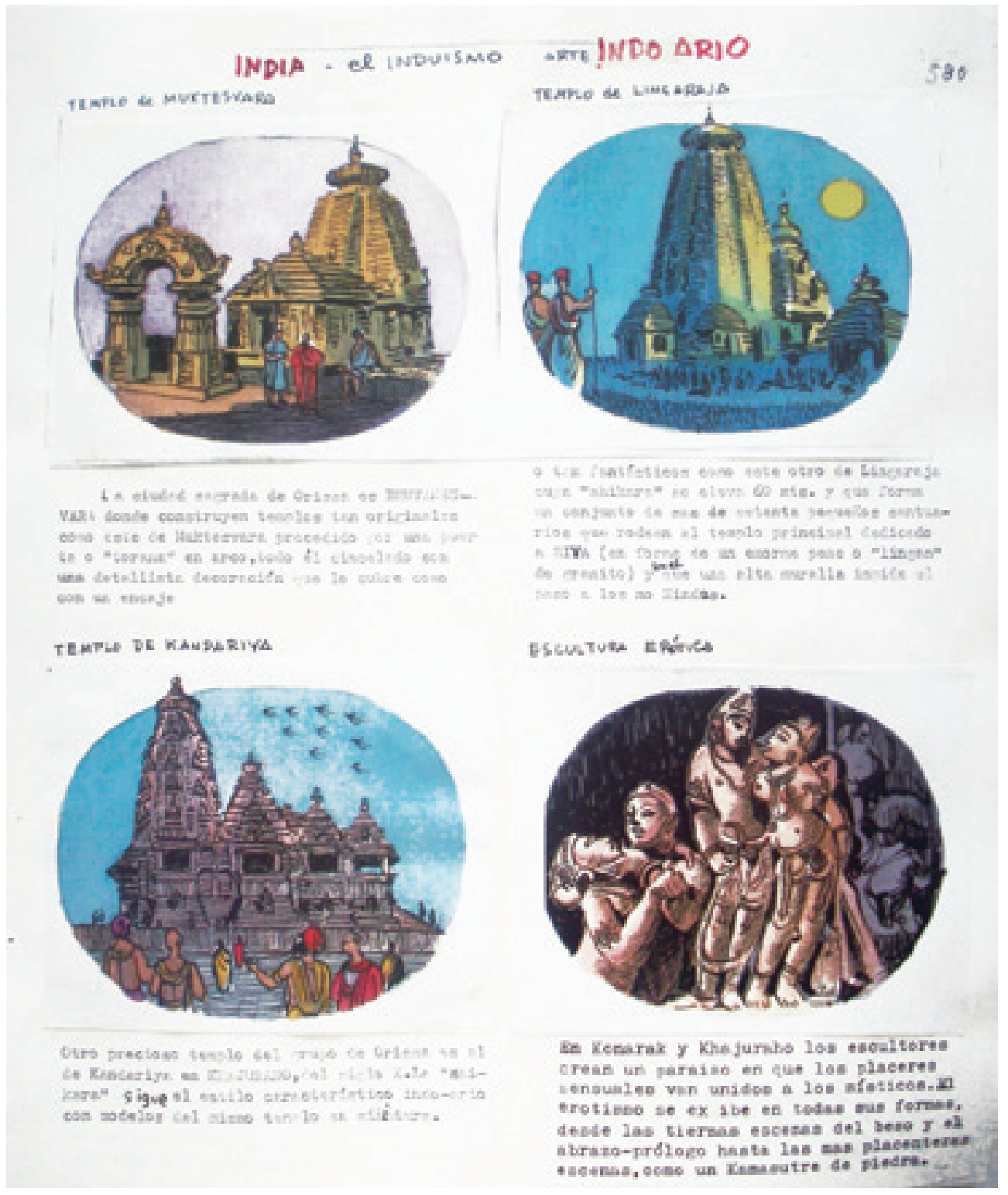




\section{e varia}

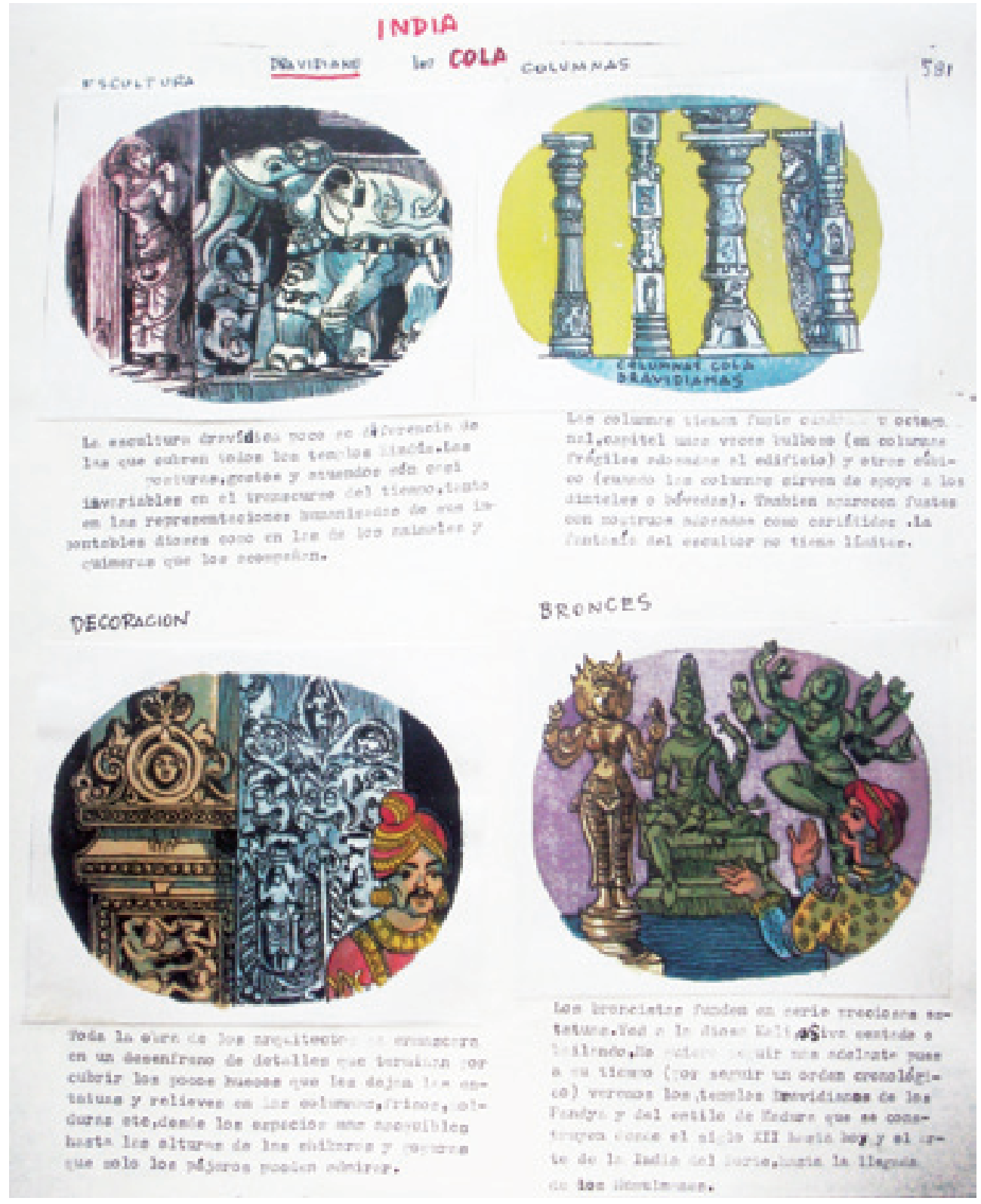




\section{e varia}

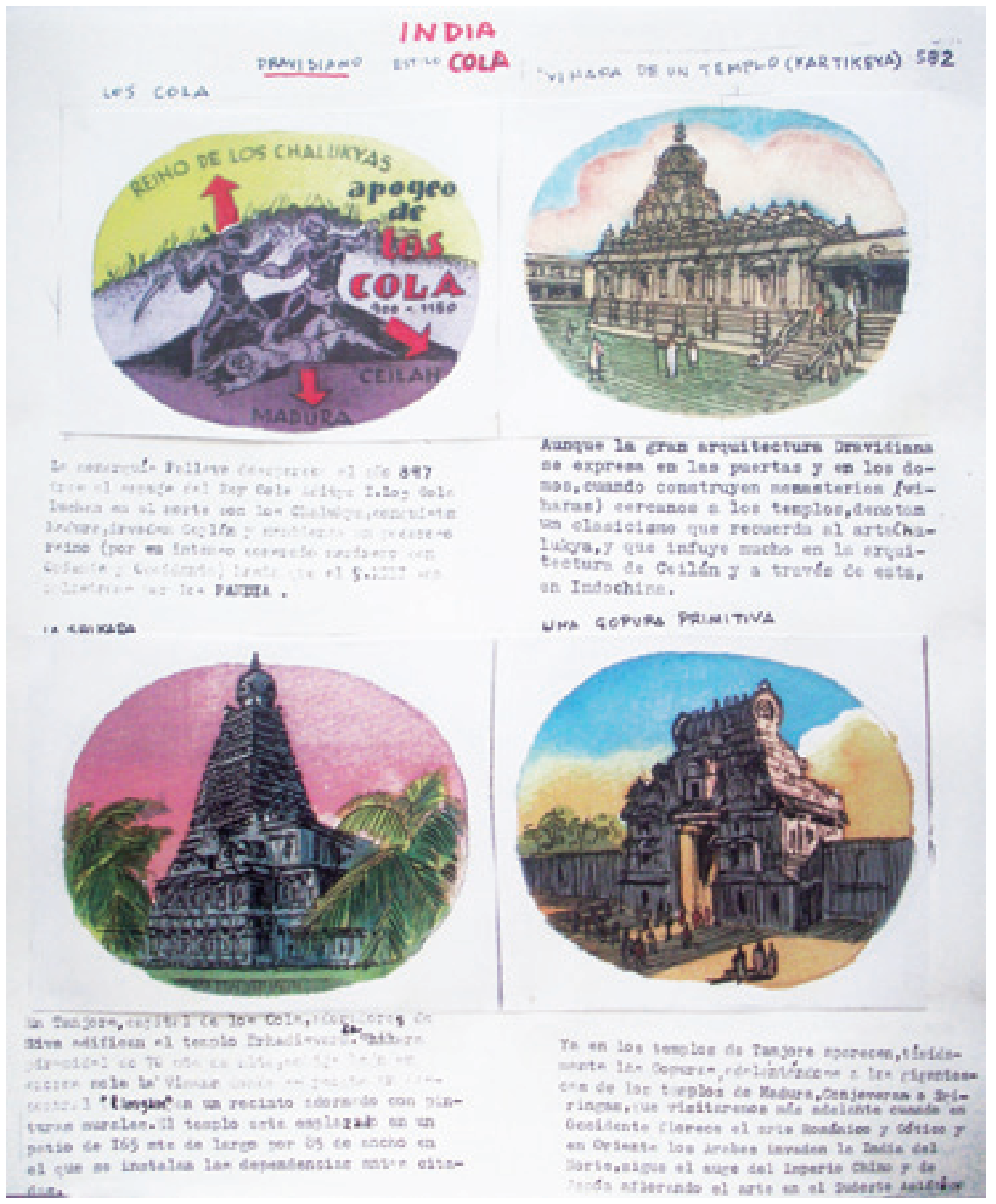




\section{O varia}

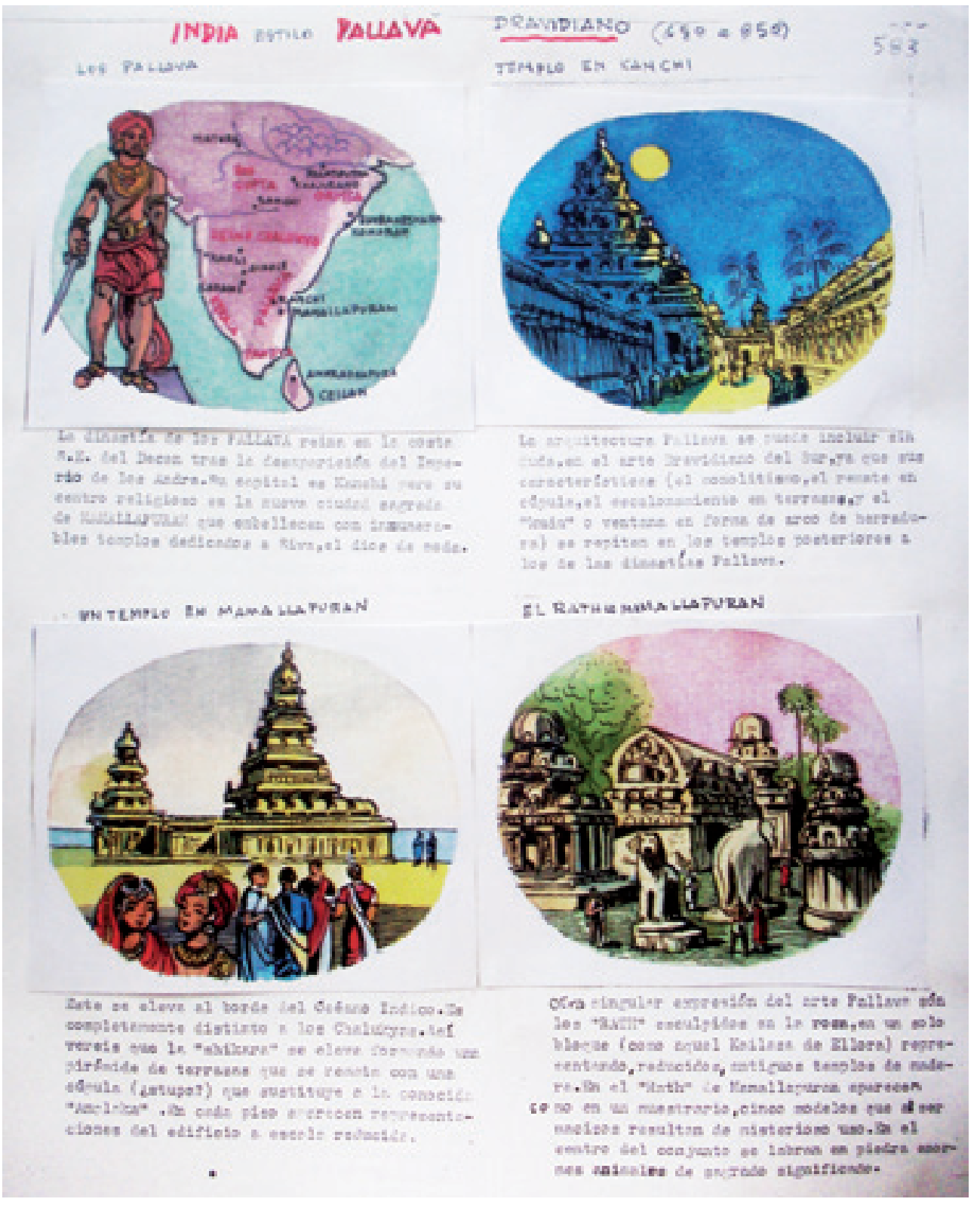




\section{E varia}

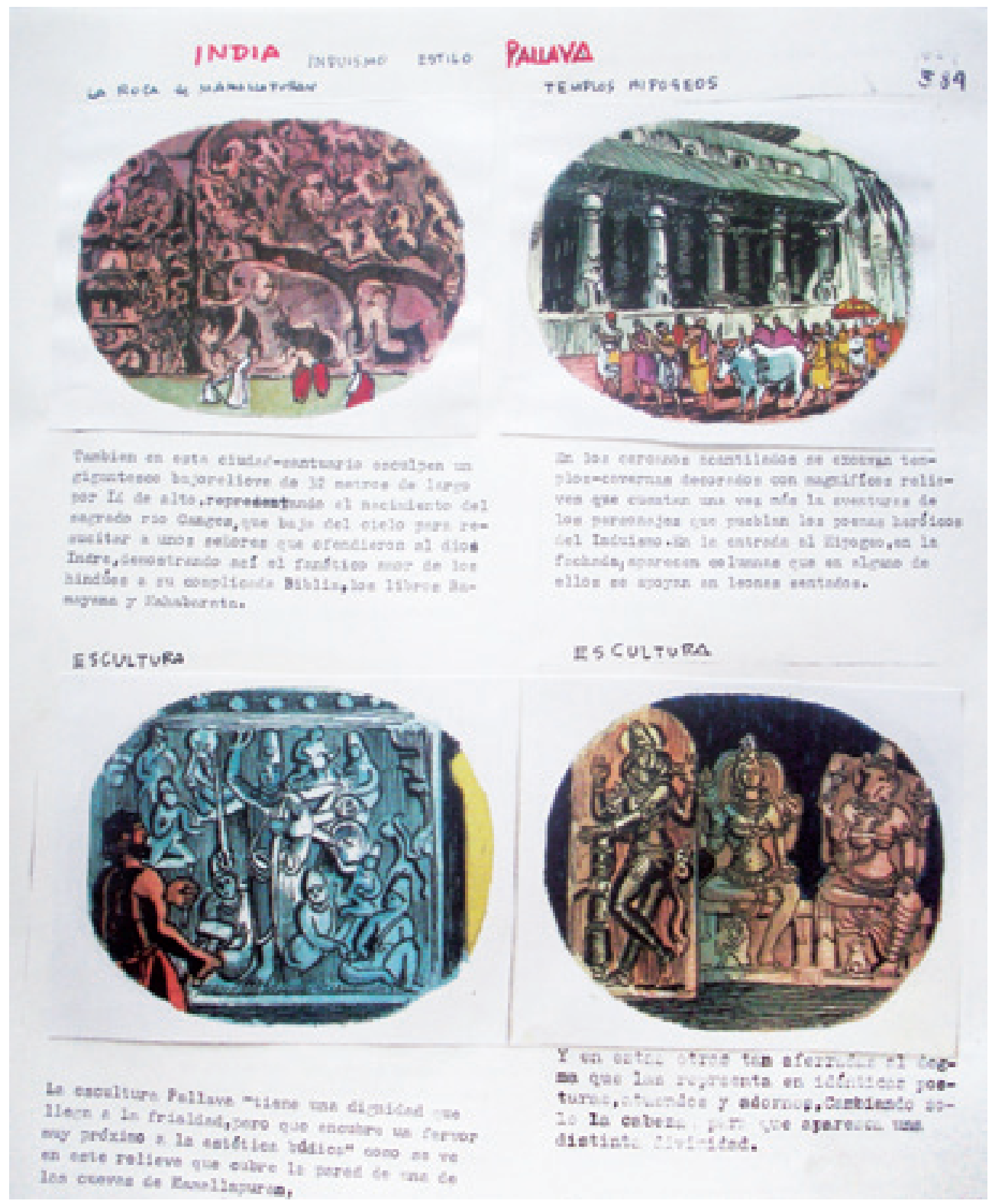




\section{e varia}

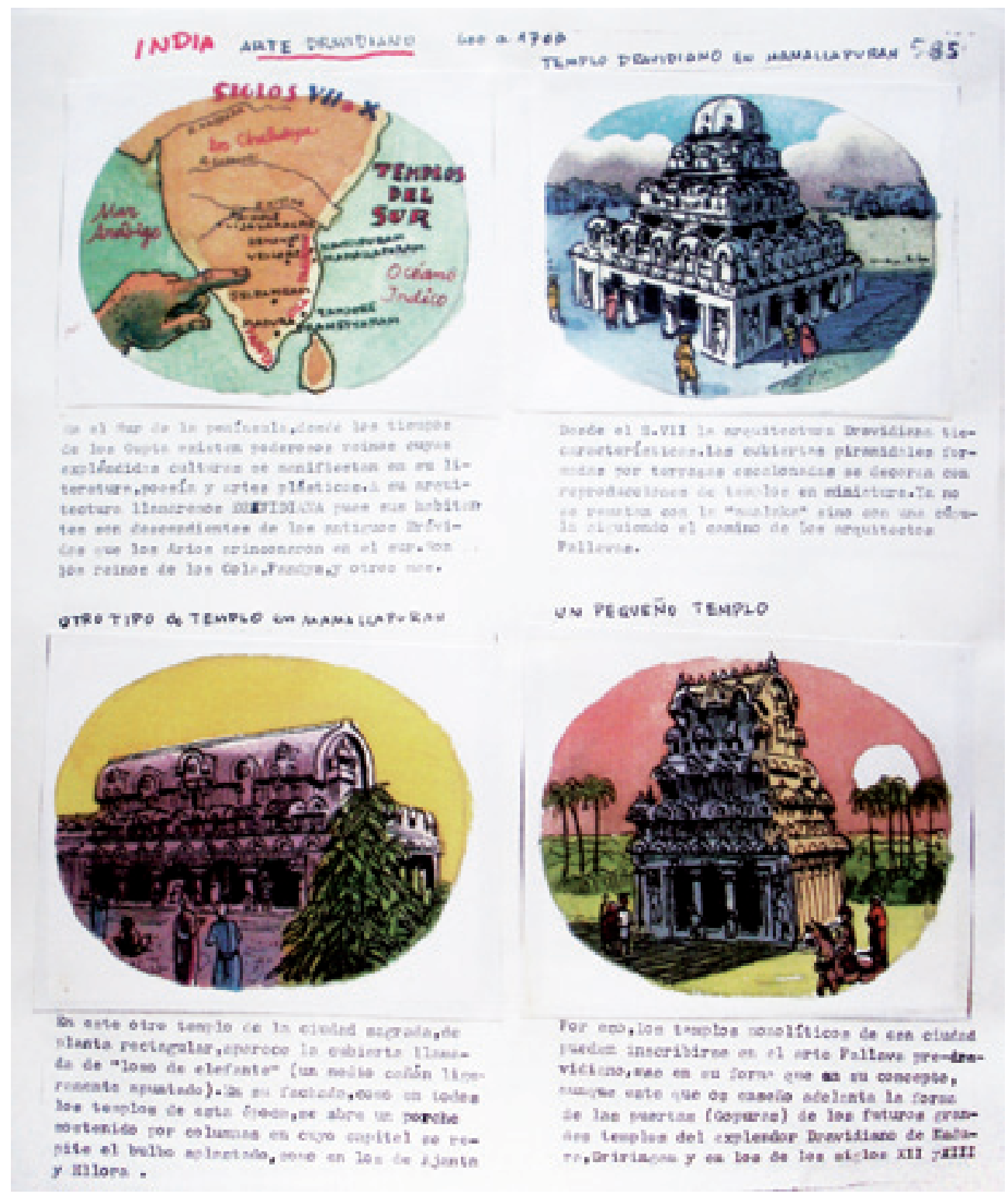




\section{SEvaria}

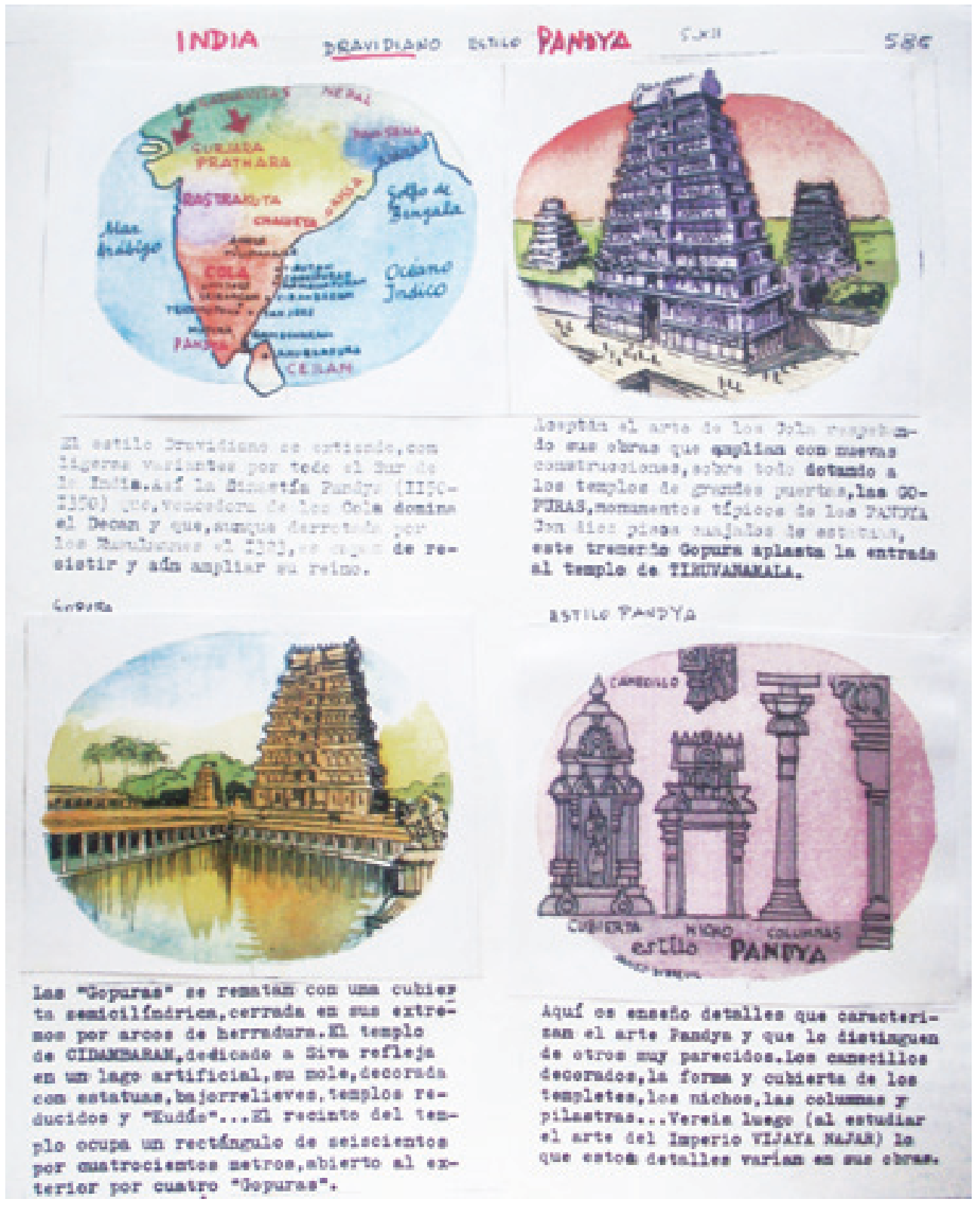




\section{e varia}

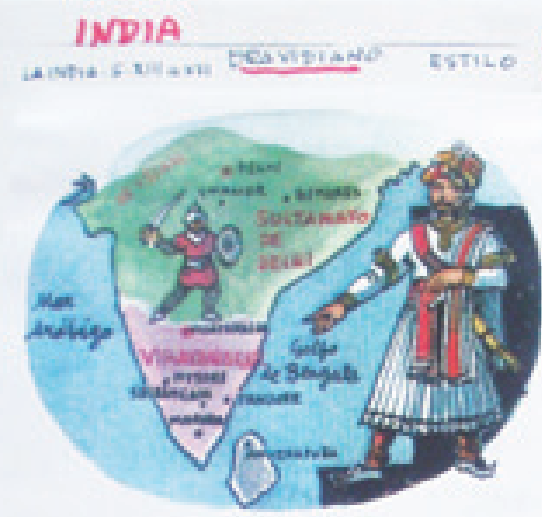

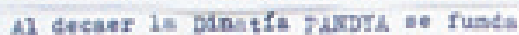
el reino de viJaYniagal, Auegue os posterior a la Alta Bed Redis, semetruye out obra: al tetilo Dravidiane, por le que no tengo nas reasdio que exponerlas akera.
VISMANAJAR 5 XIYAXVI

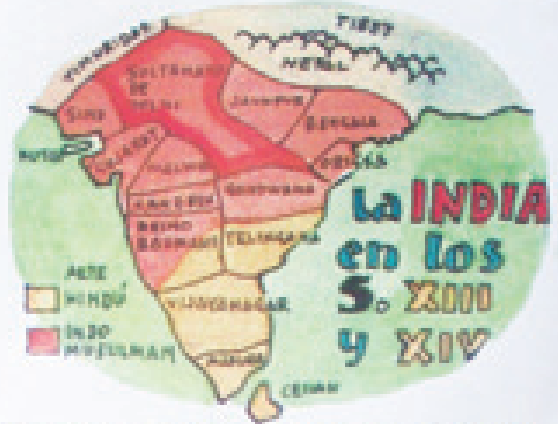

Lise el eapage del Inlas, el Inperio Vijaysmagar of refugia en ol sur (pare. renacer pederose on 1340) $y$ \& Decfa se descospont in pectutlios pero flortelentes reinos, que eonpiten en erear obrse ceda vas bas bellas. Jen 100 rednos de Yadurs, Tanjert, 1 woort,....

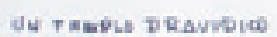

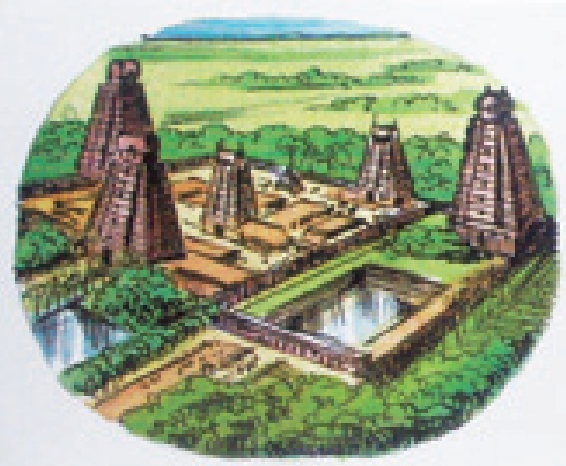

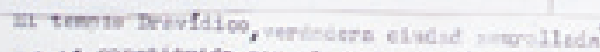
entr constituido for el matesplo (vanga) cen curcis in inicea dal diso y nolo nintsto

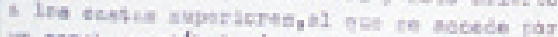

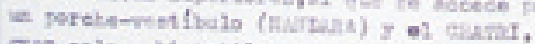

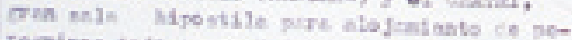

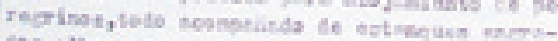

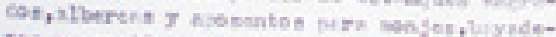
roa 7 servileres.
PUNTA LL TINGO

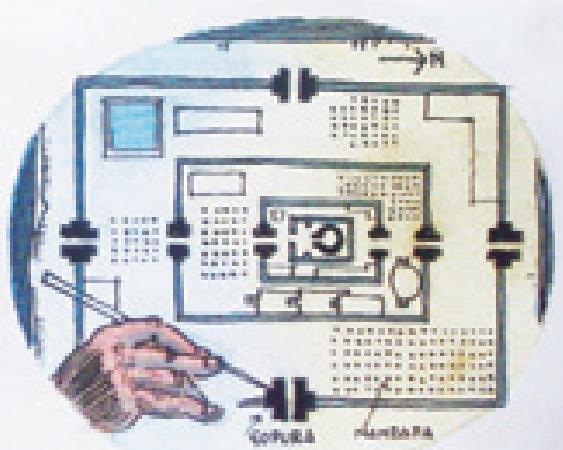

Surge la obeesibn por encrablecer los tetaploe exietentee afladifadoles baves (Wantapae) que scogen a dioats $\mathrm{y}$ diosa modes, dansarimas sacrudas $y$ eeneentra olobes de fieles. Bas trebes, de lesas, eon tuatentados por, a voces, elentos de oolumas. 


\section{E varia}

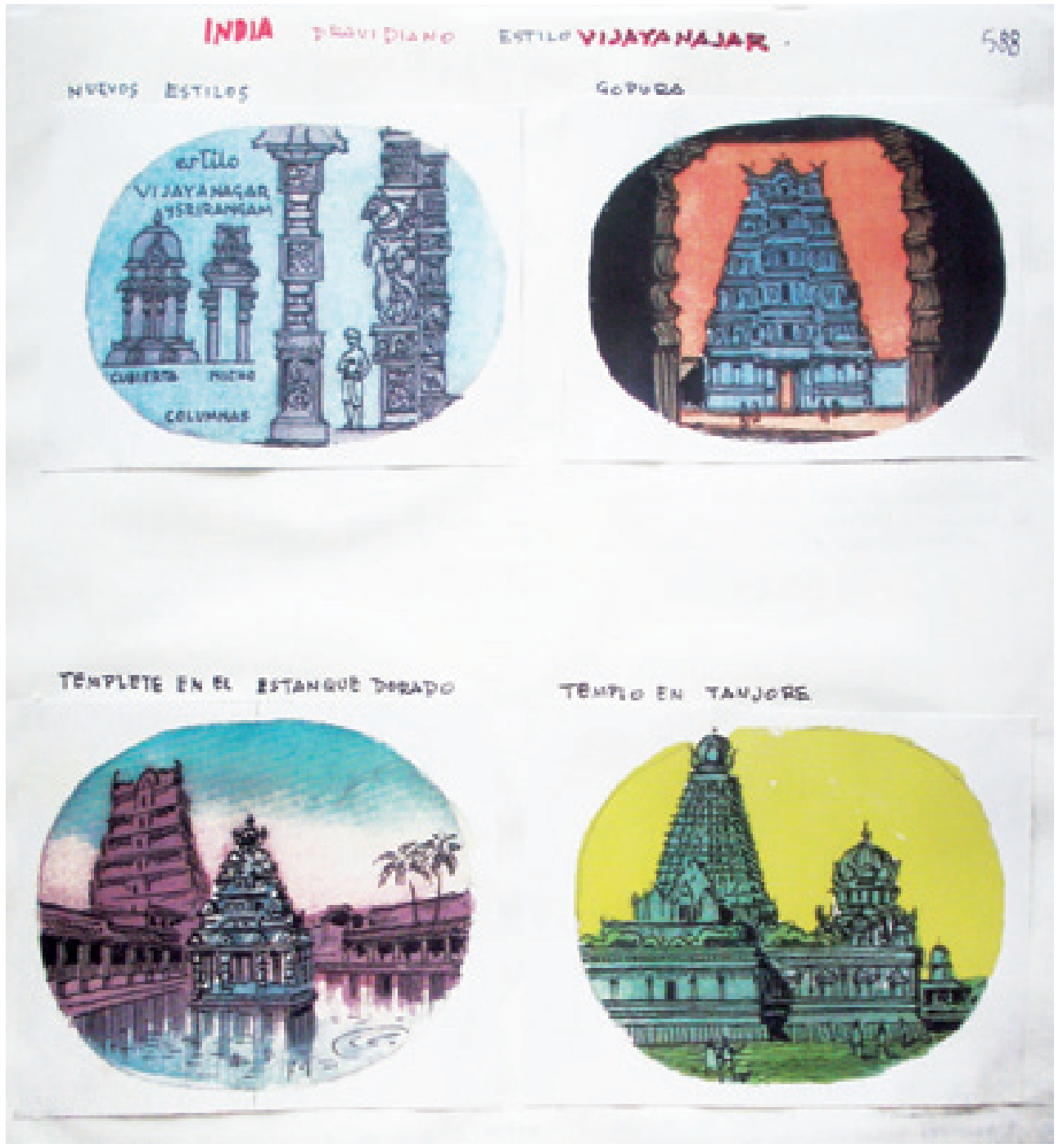




\section{VET?}

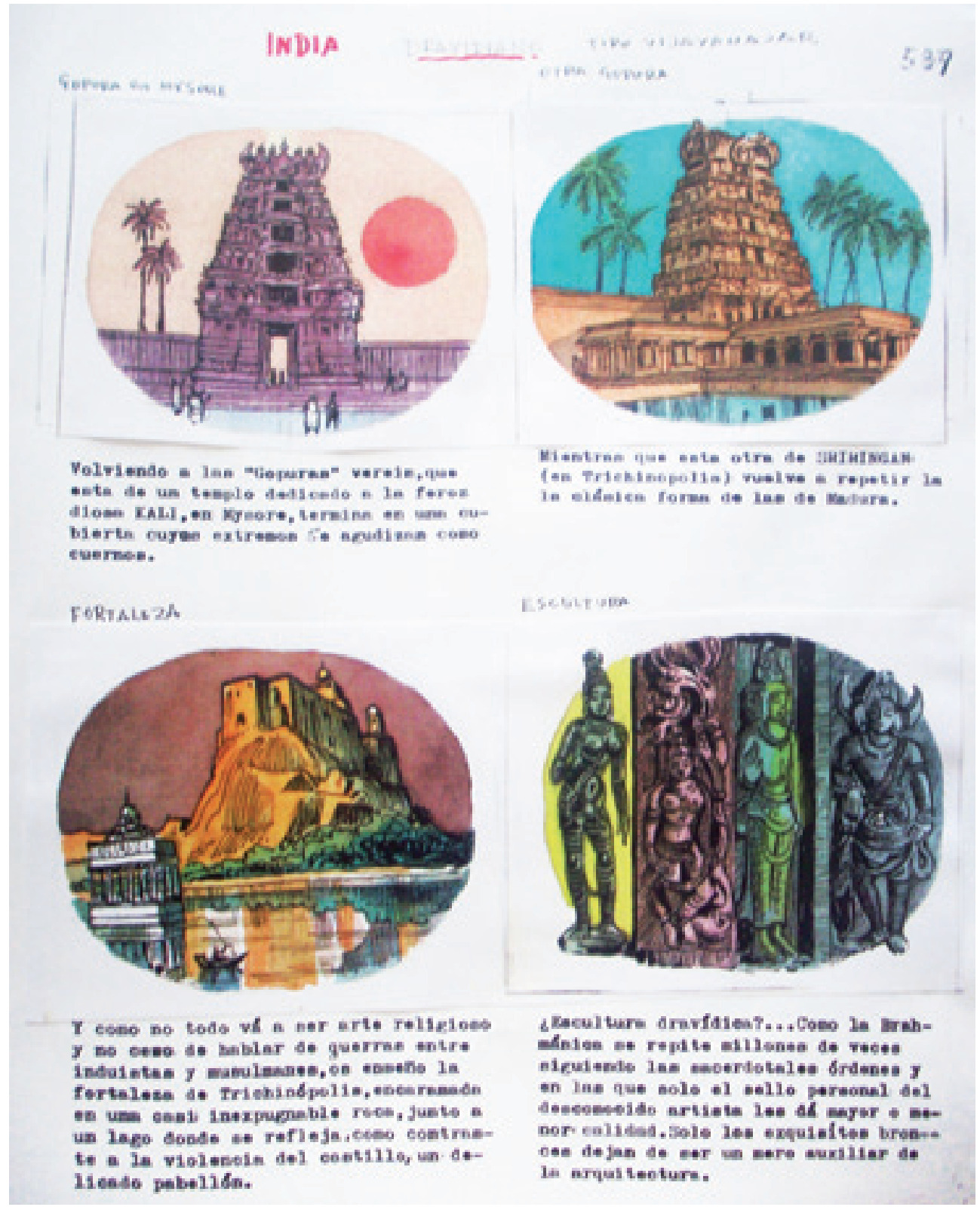




\section{OE varia}

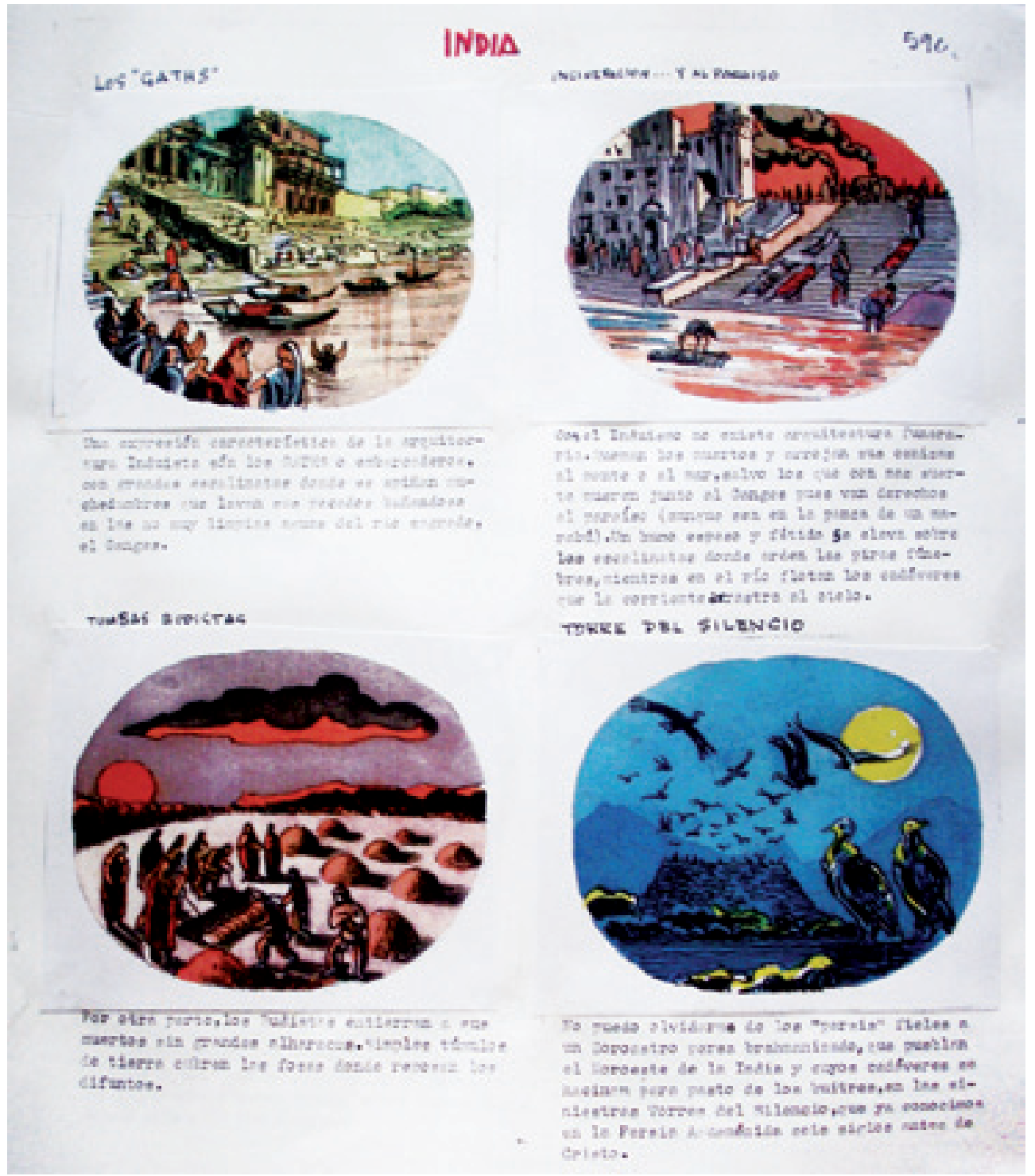




\section{E varia}

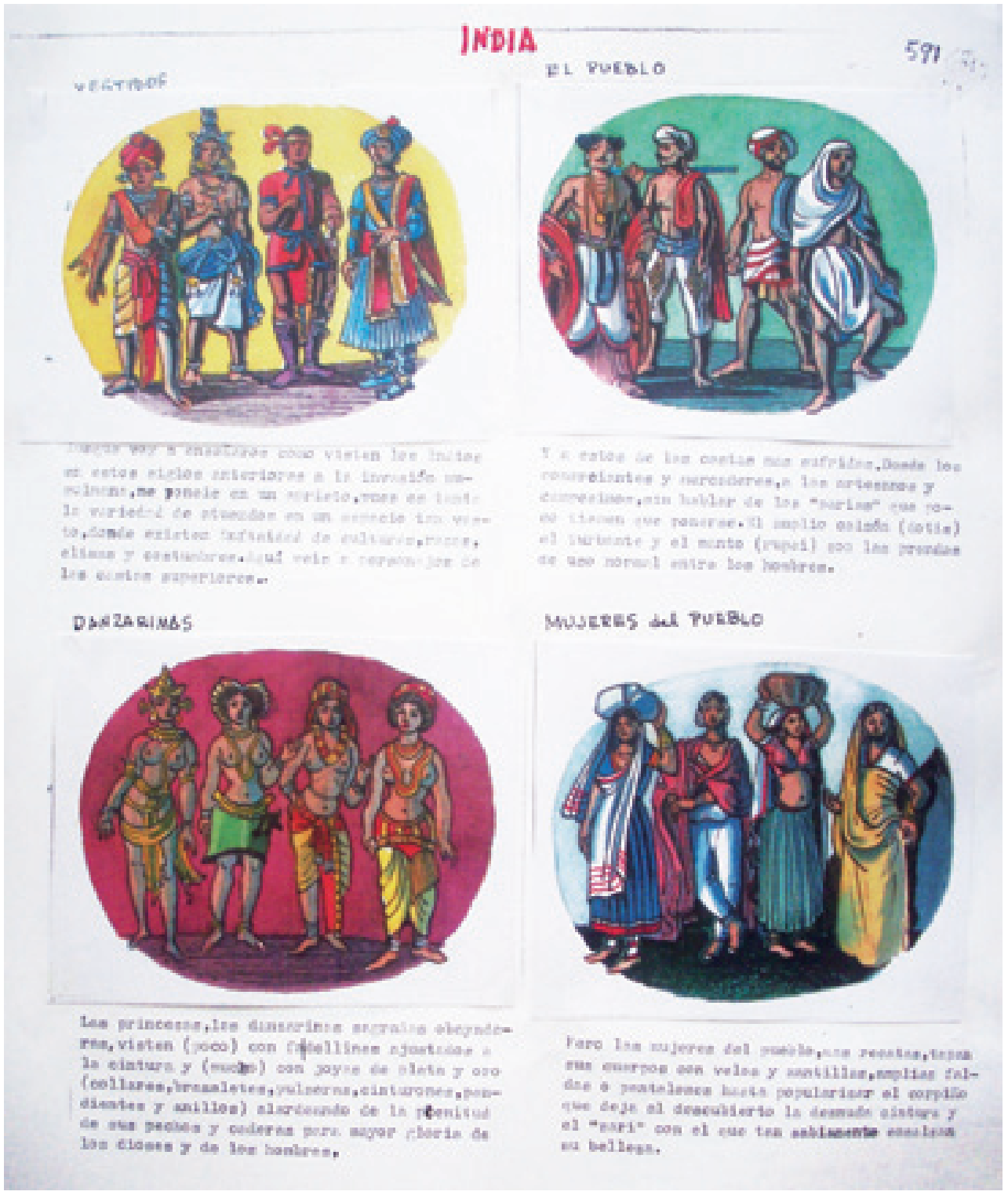




\section{E varia}

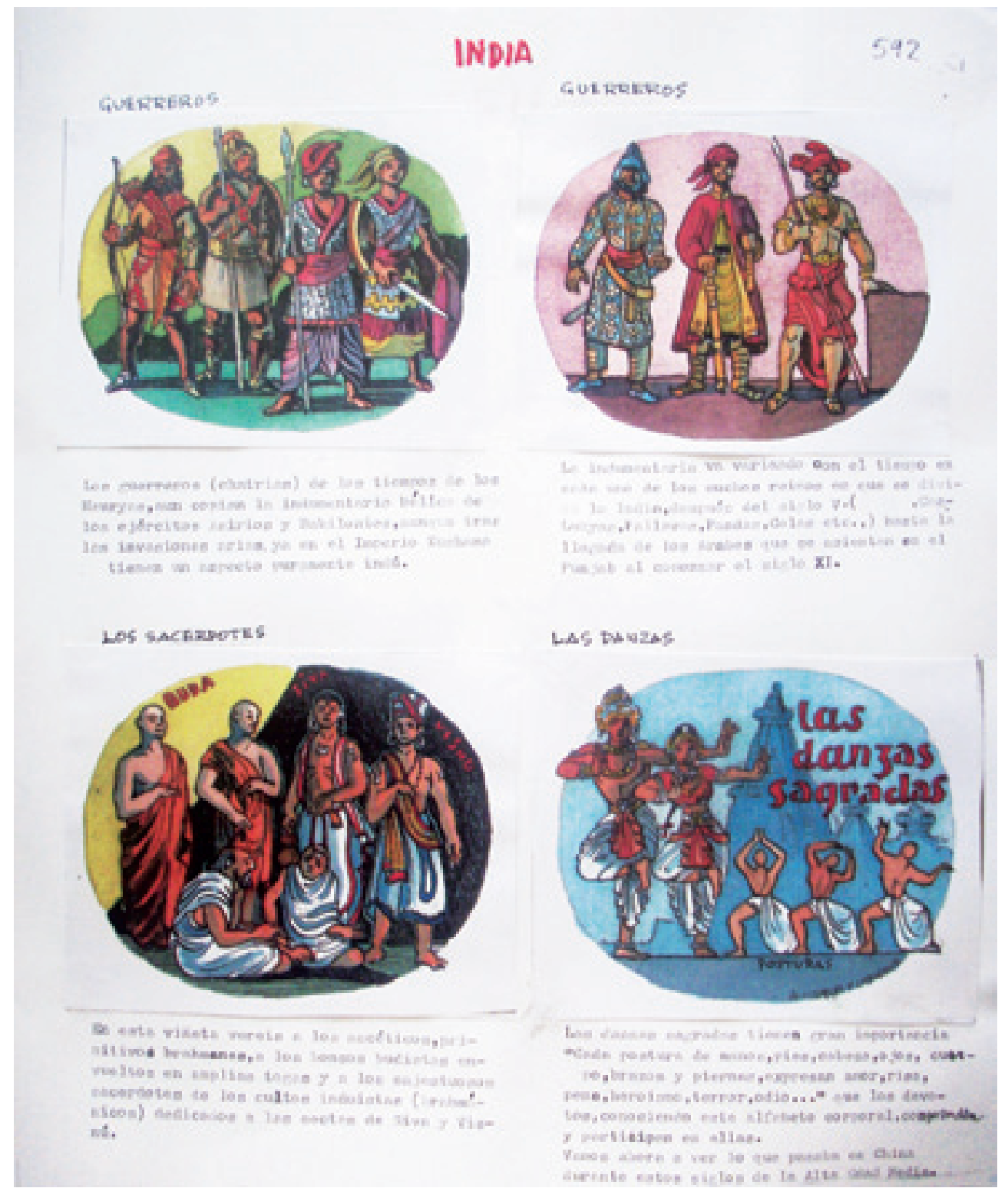

